\title{
Pressurized Solid Oxide Fuel Cells with Reformate as Fuel
}

\author{
C. Willich ${ }^{\mathrm{a}}$, C. Westner ${ }^{\mathrm{a}}$, M. Henke ${ }^{\mathrm{a}}$, F. Leucht ${ }^{\mathrm{a}}$, J. Kallo ${ }^{\mathrm{a}}$, U. Maier ${ }^{\mathrm{b}}$, K.A. Friedrich ${ }^{\mathrm{a}}$ \\ ${ }^{a}$ German Aerospace Centre (DLR), Pfaffenwaldring 38-40, 70569 Stuttgart, Germany \\ ${ }^{\mathrm{b}}$ ElringKlinger AG, Max-Eyth-Straße 2, 72581 Dettingen/Erms
}

\begin{abstract}
In this contribution the influence of pressure on an SOFC is studied with steam-reformed methane as a fuel. Experiments were performed with a reformate containing $58.4 \% \mathrm{H}_{2}, 20 \% \mathrm{H}_{2} \mathrm{O}$, 12.2\% CO, 5.5\% $\mathrm{CO}_{2}$ and $3.9 \% \mathrm{CH}_{4}$ and another mixture containing $18 \% \mathrm{H}_{2}, 34 \% \mathrm{H}_{2} \mathrm{O}, 2 \% \mathrm{CO}, 27 \% \mathrm{CO}_{2}$ and $19 \% \mathrm{CH}_{4}$ as well as a hydrogen/nitrogen mixture. The influence of pressure on OCV, power density at constant voltage and constant current as well as on gas composition was examined for the different fuels. Power density increases of up to $70 \%$ were found.
\end{abstract}

\section{Introduction}

The demand for electrical energy increases and will continue to increase. Therefore new power plants with high efficiencies and low emissions have to be developed. A hybrid power plant consisting of a pressurized solid oxide fuel cell (SOFC) system coupled with a gas turbine is seen to fulfill both requirements because such a power plant may reach electrical efficiencies above $60 \%$ with low emissions (1). This kind of hybrid power plant also has the advantage of being suitable for a wide range of applications ranging from several $10 \mathrm{~kW}$ to the MW class. The German Aerospace Center (DLR) aims at setting up a hybrid power plant in the $50 \mathrm{~kW}$ class starting in 2013. For developing this power plant the Institute of Technical Thermodynamics (TT) and the Institute of Combustion Technology (VT) at DLR combine their expertise in fuel cells and gas turbine technology. The SOFC system is developed at the Institute of Technical Thermodynamics while the Institute of Combustion Technology focuses on the gas turbine. A schematic of the hybrid power plant is shown in Figure 1. Highest efficiencies and power are to be expected when the SOFC is operated at elevated pressures (2). In the context of the hybrid power plant the fuel cell will be operated at elevated pressures up to 8 bar. During operation of the hybrid power plant air is compressed in the compressor of the gas turbine. It is then preheated and fed to the SOFC system. The off-gases of the SOFC system are used in the combustion chamber of the gas turbine where additional fuel may be added for example for starting the system. After expansion of the gas in the gas turbine the offgas is used to preheat the air for the fuel cell system.

For the realization of the power plant it is necessary to understand the behavior of each subsystem as well as their interactions. The pressurized solid oxide fuel cell is an essential part of the system but there is still little data available from literature concerning the behavior of SOFC at elevated pressures. Since it cannot quantitatively be derived from measurements at ambient pressure because of complex and interdependent 
mechanisms taking place at the cell, a test rig for the characterization of SOFC stacks exposed to pressures up to 8 bar has been built at DLR (3).

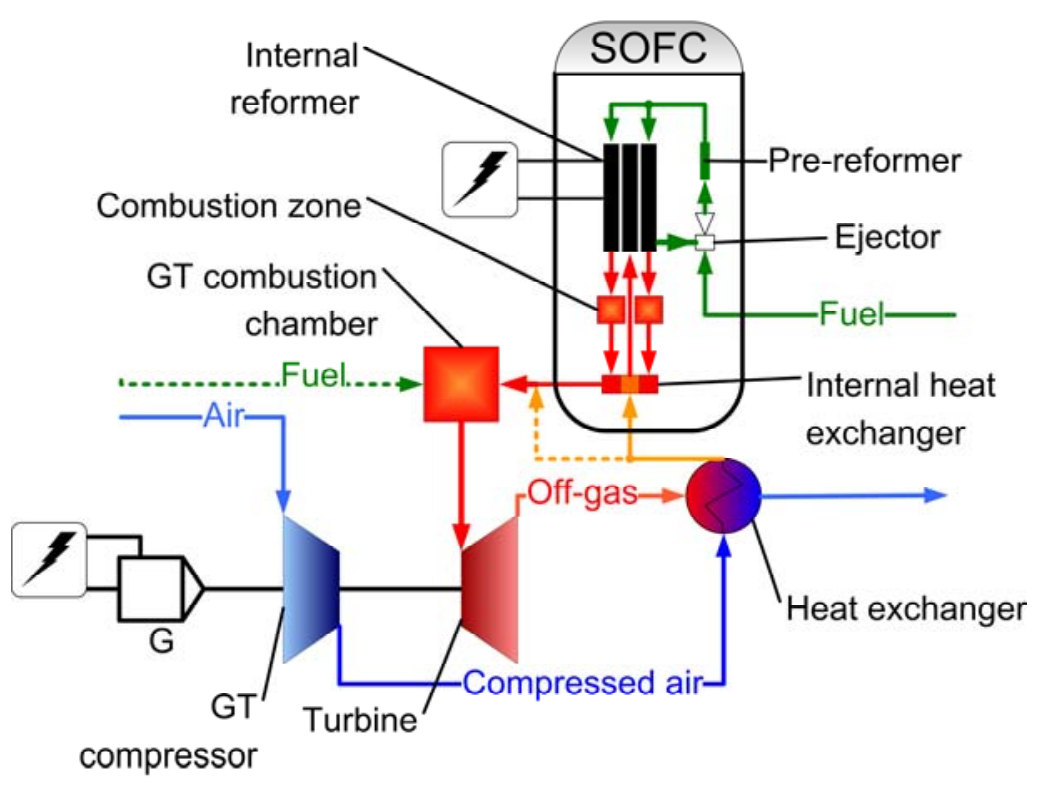

Figure 1: Schema of a hybrid power plant consisting of an SOFC system and a gas turbine.

The hybrid power plant will eventually run on natural gas, therefore the SOFC stack will be operated with prereformed reformate gases. The effect of elevated pressure on reformate gas composition, reforming reactions, electrochemical processes and the general behavior of the cells are of great interest. The knowledge of steady state as well as transient operational behavior and of course of operational limits is essential for the integration of the SOFC into the hybrid power plant system.

\section{Experimental setup}

In the pressurized SOFC test rig SOFC short stacks can be characterized at pressures of 1 to 8 bar. Pressure difference between anode and cathode gas compartments and the furnace can be controlled by a pressure control system up to 500 mbar. This pressure control is important to keep pressure differences low since a large pressure difference may lead to the destruction of the cells or stack. To control the pressure difference between anode, cathode and the furnace two equalizing tanks of $400 \mathrm{l}$ each are used balancing the small volumes of the anode and cathode gas compartment against the far greater volume of the furnace.

The maximum temperature for testing is $950^{\circ} \mathrm{C}$ and the stack in the test rig can be supplied with mixtures of hydrogen, nitrogen, methane, carbon monoxide, carbon dioxide and steam on the anode side that can be mixed to represent reformate gases. At the cathode air, oxygen, nitrogen and helium are available. The test rig offers the possibility 
to measure current-voltage characteristics of the stack and its individual cells as well as performing impedance spectroscopy on the cells. The gas composition at the in- and outlet of the anode and cathode can be measured by means of a gas chromatograph (3).

For the results presented here anode-supported 5-cell short stacks provided by ElringKlinger AG with an active area of $84 \mathrm{~cm}^{2}$ per cell were used. They consist of sintered cells which are integrated into stamped metal sheet bipolar plates as shown in Figure 2. These are referred to as cassettes. The cells consist of an anode substrate (Ni/YSZ) and functional layer. The YSZ electrolyte is $10 \mu \mathrm{m}$ thick and the cathode consists of two layers, a functional layer made of LSM/YSZ and a current collector made of LSM.

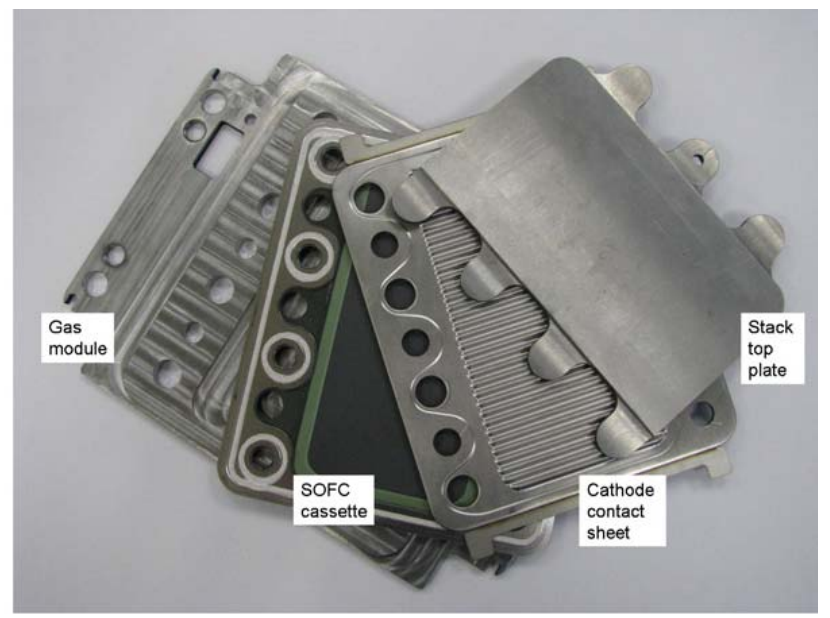

Figure 2: Cell integrated into metal bipolar plates.

Measurement were done with a 1/1 hydrogen/nitrogen mixture with a water content of $3 \%$, a partially reformed reformate containing $18 \% \mathrm{H}_{2}, 34 \% \mathrm{H}_{2} \mathrm{O}, 2 \% \mathrm{CO}, 27 \% \mathrm{CO}_{2}$ and $19 \% \mathrm{CH}_{4}$ (reformate 1 ) as well as a steam-reformed reformate containing $58.4 \% \mathrm{H}_{2}$, $20 \% \mathrm{H}_{2} \mathrm{O}, 12.2 \% \mathrm{CO}, 5.5 \% \mathrm{CO}_{2}$ and $3.9 \% \mathrm{CH}_{4}$ (reformate 2). The temperature was varied between $700^{\circ} \mathrm{C}$ and $800^{\circ} \mathrm{C}$ and pressure variations were done ranging from 1.35 bar up to 8 bar. The flow rate for the hydrogen/nitrogen mixture was $5 \mathrm{l} / \mathrm{min}$ of hydrogen. The flow rate for the reformates was chosen to obtain the same theoretical current as for $\mathrm{H}_{2} / \mathrm{N}_{2}$ resulting in a total flow rate of $5.63 \mathrm{l} / \mathrm{min}$ for the first reformate and $5.06 \mathrm{l} / \mathrm{min}$ for the second. The results shown in this contribution are for one of the cells from the middle of the stack since outer cells often show a deviation in performance due to temperature effects (4).

\section{Results}

In Figure 3 to Figure 4 current voltage characteristics for one cell from the middle of the stack at different pressures can be seen for the three gas compositions at $700^{\circ} \mathrm{C}$ and $800^{\circ} \mathrm{C}$. Each diagram shows the current-voltage curves for one gas composition and one temperature at different pressures. It can be seen in these diagrams that elevated pressure leads not only to a higher OCV but also affects the gradient of the curve under load. This 
can be seen for all gas compositions and temperatures. The higher the current density the greater is the difference between the $\mathrm{i}-\mathrm{V}$ curves for the different pressures. In the following chapters the behaviour shown in the characteristic curves is examined more closely.
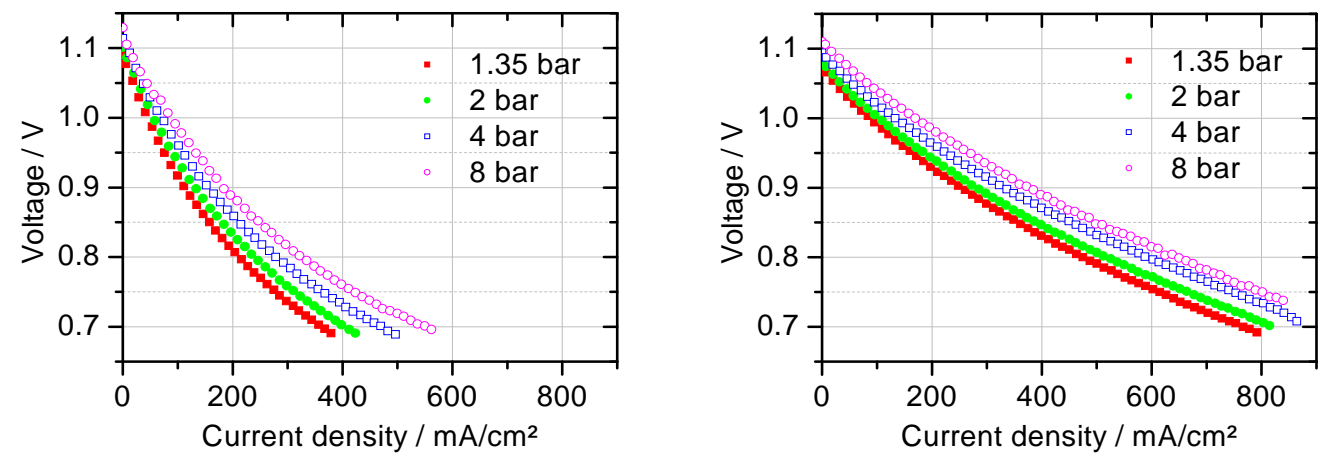

Figure 3: Pressure dependent current voltage curves for $\mathrm{H}_{2} / \mathrm{N}_{2}$ at $700^{\circ} \mathrm{C}$ (left) and $800^{\circ} \mathrm{C}$ (right).
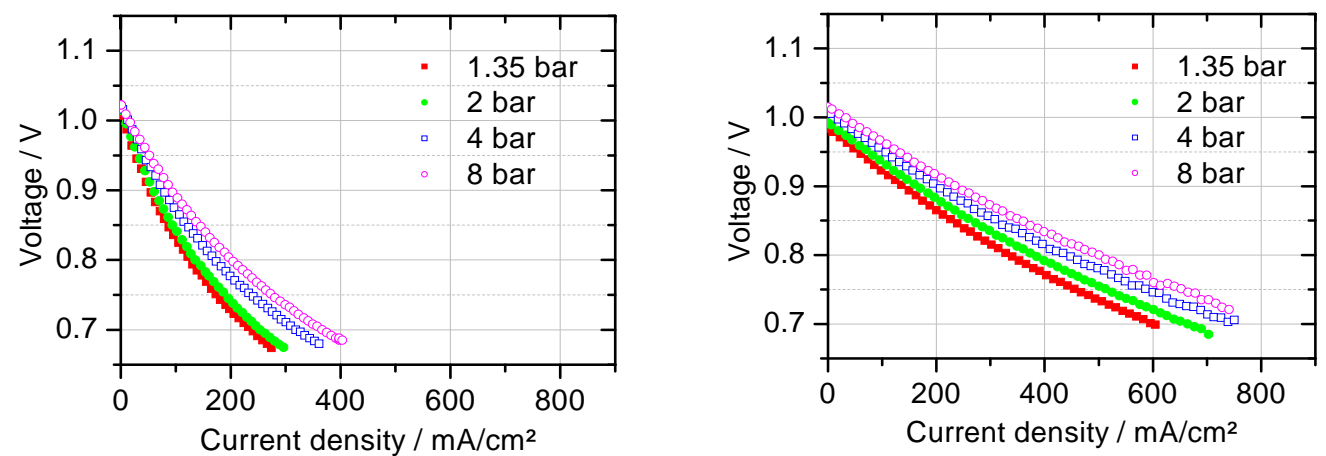

Figure 4: Pressure dependent current voltage curves for reformate 1 at $700^{\circ} \mathrm{C}$ (left) and $800^{\circ} \mathrm{C}$ (right).
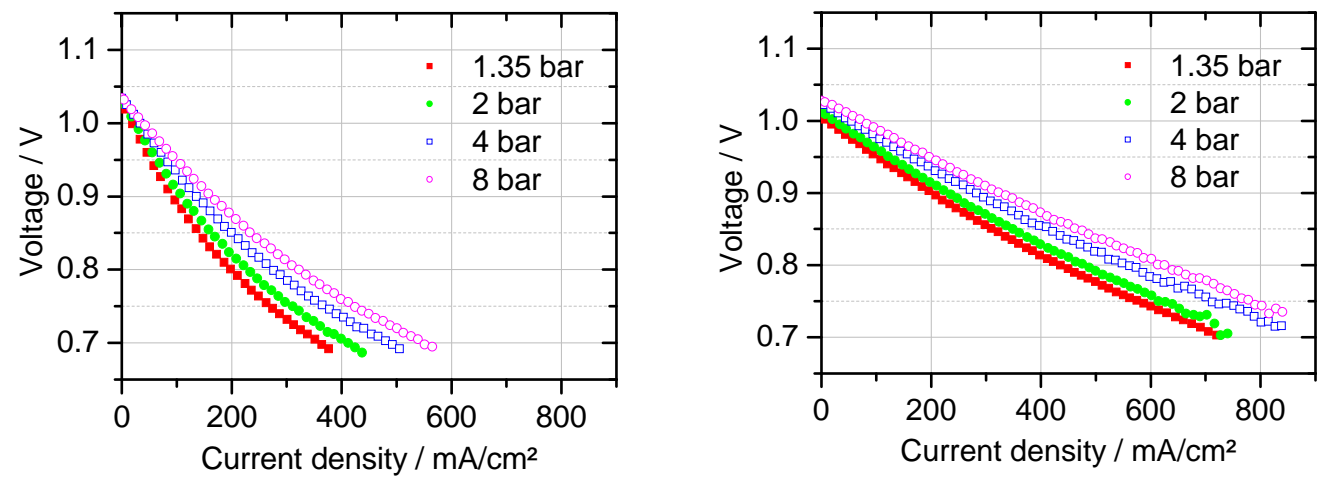

Figure 5: Pressure dependent current voltage curves for reformate 2 at $700^{\circ} \mathrm{C}$ (left) and $800^{\circ} \mathrm{C}$ (right). 


\section{Pressure influence on gas composition and open circuit voltage}

Figure 6 shows the development of OCV of one cell from the middle of the stack with increasing pressure for the three different gas compositions that were examined. The squares show the experimentally obtained values. The lines show the theoretical OCV that was calculated using equation [1] and assuming equilibrium composition of the fuel at the cell. For determining equilibrium composition and OCV the open-source software CANTERA (5) was used.

$$
\mathrm{OCV}=-\frac{\mathrm{RT}}{2 \mathrm{~F}} \ln \frac{\sqrt{\mathrm{P}_{\mathrm{O}_{2} \text {,cathode }}}}{\sqrt{\mathrm{P}_{\mathrm{O}_{2} \text {,anode }}}}
$$

Filled symbols are experimental values at $800^{\circ} \mathrm{C}$ while open symbols represent measurements at $700^{\circ} \mathrm{C}$. The continuous lines are calculated for $800^{\circ} \mathrm{C}$ and the dotted lines for $700^{\circ} \mathrm{C}$. Colour and symbol shape stand for the three different gas compositions measured. Calculated and experimental values show similar tendencies. For all gas compositions OCV increases with pressure but not to the same extend. Temperature has an influence on the OCV and its increase through pressure. The hydrogen/nitrogen mixture shows a greater increase in OCV than the reformate gases. For the following comparisons theoretical OCV values are taken. For a pressure increase from 1.35 bar to 8 bar the OCV of the hydrogen/nitrogen mixture rises by $40 \mathrm{mV}(3.7 \%)$ at $800^{\circ} \mathrm{C}$ while for reformate 1 it rises only $30 \mathrm{mV}$ (3.1\%) and for reformate 2 by $23 \mathrm{mV}$ (2.3\%). The increase in OCV through pressure at different temperatures varies only slightly for the $\mathrm{H}_{2} / \mathrm{N}_{2}$ mixture. At $700^{\circ} \mathrm{C}$ the increase is $36 \mathrm{mV}$ (3.3\%) compared to the $40 \mathrm{mV}$ (3.7\%) at $800^{\circ} \mathrm{C}$ mentioned above. For the reformate gases temperature has a stronger influence on OCV increase through pressure. For both reformates the increase in OCV remains below $10 \mathrm{mV}$ for a temperature of $700^{\circ} \mathrm{C}(9 \mathrm{mV}$ or $0.9 \%$ for reformate 1 and $4 \mathrm{mV}$ or $0.4 \%$ for reformate 2). In the case of the reformates the lower temperature leads to a higher OCV at low pressures, but at high pressures the difference in OCV because of temperature gets smaller. For reformate 2 the OCV at 8 bar is almost the same for both temperatures.

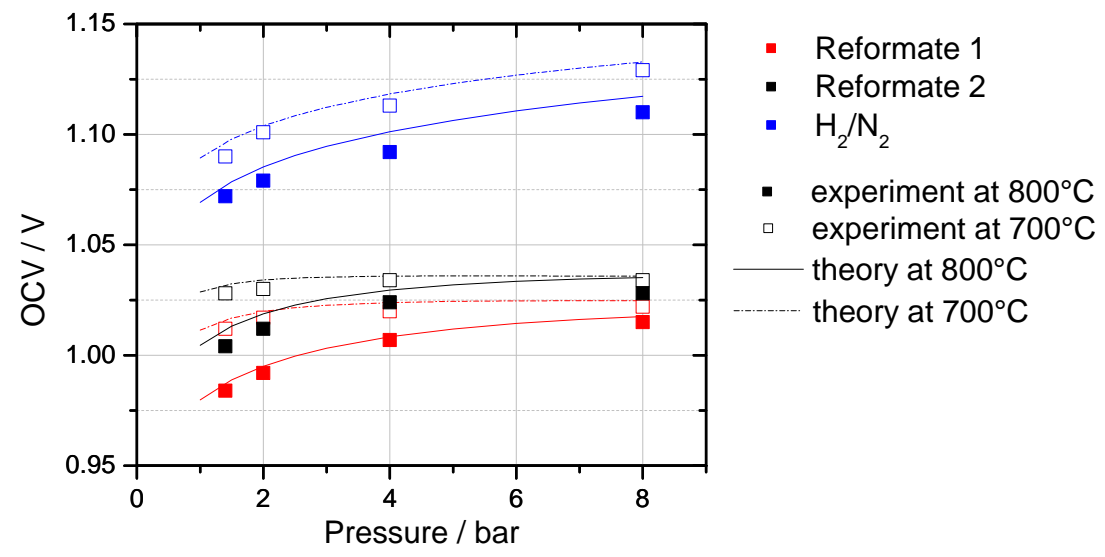

Figure 6: Pressure and temperature dependence of OCV for three different gas compositions 
This can be explained by looking at the pressure dependency of the equilibrium compositions of the reformate gases at different temperatures. The lines in Figure 7 show the calculated equilibrium compositions for reformate 1 that were determined using CANTERA for pressures ranging from 1 to 8 bar for $700^{\circ} \mathrm{C}$ and for $800^{\circ} \mathrm{C}$. The symbols are the gas compositions that were measured at OCV after the stack for the different conditions using a gas chromatograph. The measured values match well with the theoretical equilibrium composition, although there is a discrepancy especially for the water content.

At $700^{\circ} \mathrm{C}$ the gas composition varies far more with pressure than at $800^{\circ} \mathrm{C}$. The higher the pressure the smaller is the hydrogen and $\mathrm{CO}$ content of the equilibrium fuel gas. While at $800^{\circ} \mathrm{C}$ the hydrogen content decreases from $46 \%$ to $41 \%$ for the theoretical equilibrium and stays constant in the measurements, it decreases at $700^{\circ} \mathrm{C}$ from $46 \%$ to $32 \%$ for the theoretical equilibrium and from $48 \%$ to $36 \%$ for the measured values. The pressure increase leads to an increase in OCV of the cell but it also leads to a less favourable gas composition with smaller fuel content which is decreasing this OCV gain through pressurization.
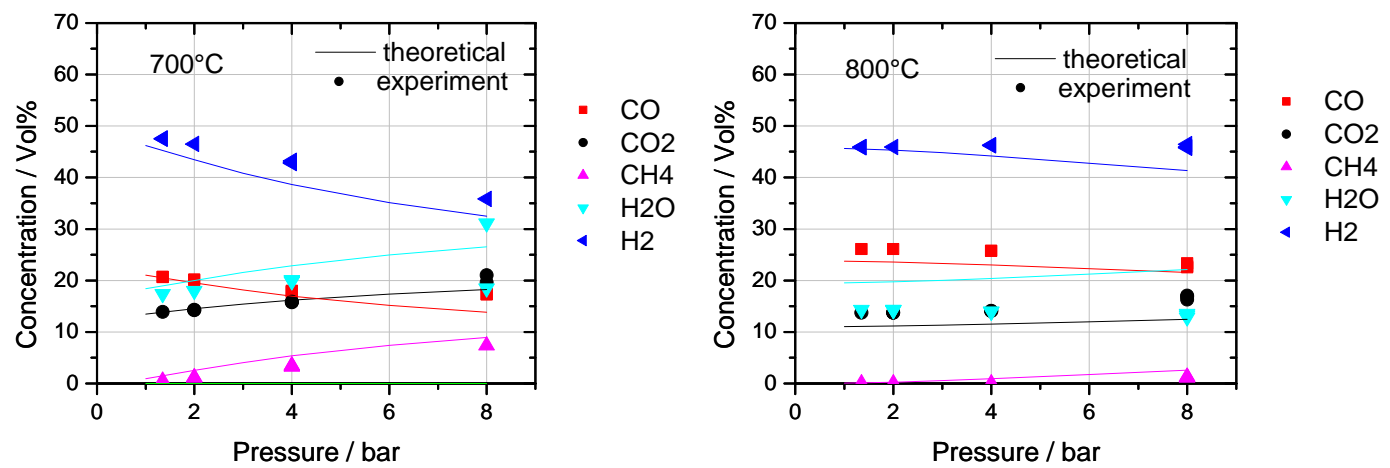

Figure 7: Calculated equilibrium gas composition and measured values over pressure for reformate 1 at $700^{\circ} \mathrm{C}$ and $800^{\circ} \mathrm{C}$.

A similar tendency is seen for reformate 2 in Figure 8. The $\mathrm{H}_{2}$ content is higher than for reformate 1 but the decrease in hydrogen content for the theoretical equilibrium is similar to that of reformate 1 .

The calculated $\mathrm{H}_{2}$ content of the $\mathrm{H}_{2} / \mathrm{N}_{2}$ mixture hardly varies with pressure for either temperature as can be seen in Figure 9 which is why OCV rises more strongly with pressure for this fuel. 

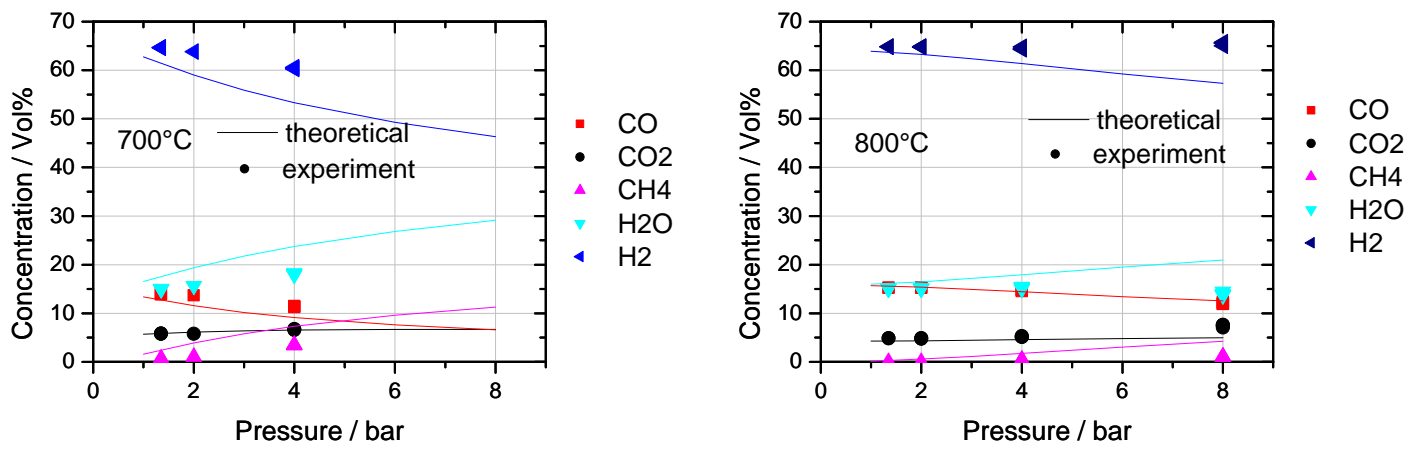

Figure 8: Calculated equilibrium gas composition and measured values over pressure for reformate 2 at $700^{\circ} \mathrm{C}$ and $800^{\circ} \mathrm{C}$.
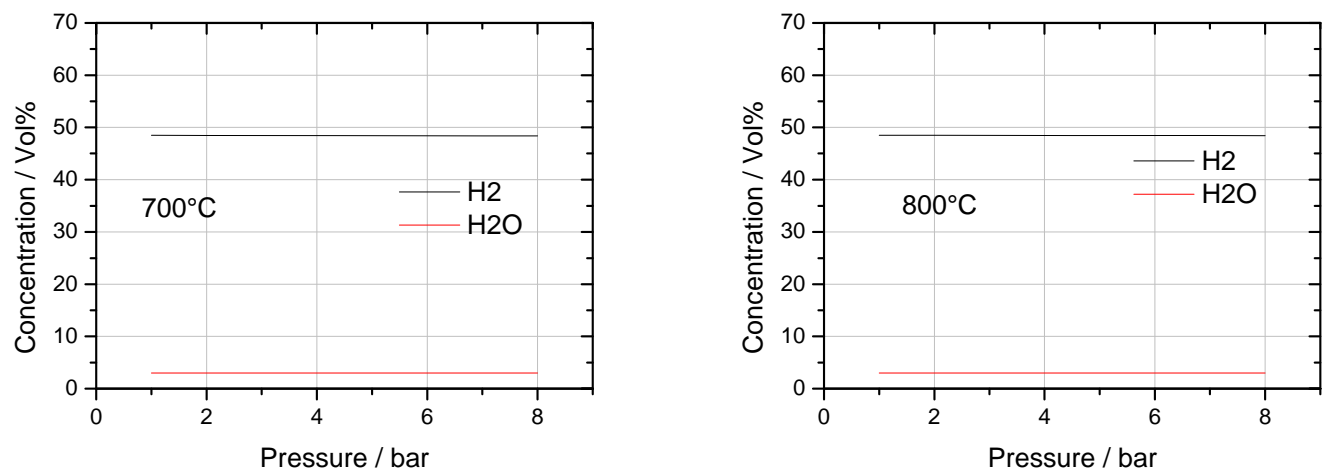

Figure 9: Calculated equilibrium gas composition over pressure for $\mathrm{H}_{2} / \mathrm{N}_{2}$ mixture at $700^{\circ} \mathrm{C}$ and $800^{\circ} \mathrm{C}$.

\section{Performance gain under pressure at constant voltage}

In Figure 10 the influence of pressure on performance at a constant voltage of 750 $\mathrm{mV}$ can be seen for the different fuels. The filled symbols are the measured values at $800^{\circ} \mathrm{C}$, the open symbols at $700^{\circ} \mathrm{C}$. The pressure dependency shows a logarithmic behavior for all fuels increasing more strongly at low pressures and leveling out at elevated pressures. At $800^{\circ} \mathrm{C}$ power density is highest for $\mathrm{H}_{2} / \mathrm{N}_{2}$ but the relative as well as the absolute power density gain through pressurization is slightly greater for the reformates. At a pressure rise from 1.35 bar to 8 bar power density at $750 \mathrm{mV}$ rises by $138 \mathrm{~mW} / \mathrm{cm}^{2}$ or $30 \%$ for the $\mathrm{H}_{2} / \mathrm{N}_{2}$ mixture, while it rises by $146 \mathrm{~mW} / \mathrm{cm}^{2}$ (42\%) for reformate 1 and by $154 \mathrm{~mW} / \mathrm{cm}^{2}$ (35\%) for reformate 2 . Here the reformate gas with the greater methane content (reformate 1) shows a smaller absolute increase but a higher relative increase than the almost entirely reformed reformate 2 . It can be seen from Figure 10 that at a constant cell voltage of $0.75 \mathrm{~V}$ the curves for $700^{\circ} \mathrm{C}$ have a smaller gradient than those for $800^{\circ} \mathrm{C}$. A lower temperature leads to a smaller increase in power density while a higher temperature leads to a stronger increase in performance with rising pressure for all fuels measured. At $700^{\circ} \mathrm{C}$ the increase with pressure for reformate 1 is 
smaller than for both the other fuels. The increase is only $78 \mathrm{~mW} / \mathrm{cm}^{2}$ if pressure is increased from 1.35 bar to 8 bar while for $\mathrm{H}_{2} / \mathrm{N}_{2}$ the increase is $106 \mathrm{~mW} / \mathrm{cm}^{2}$. Nevertheless the relative gain is highest (60\%) for reformate 1 in comparison to $51 \%$ for $\mathrm{H}_{2} / \mathrm{N}_{2}$. At $700^{\circ} \mathrm{C}$ reformate 2 and the $\mathrm{H}_{2} / \mathrm{N}_{2}$ mixture hardly differ from each other although the absolute power density increase through pressurization at $700^{\circ} \mathrm{C}$ as well as at $800^{\circ} \mathrm{C}$ was highest for reformate $2\left(115 \mathrm{~mW} / \mathrm{cm}^{2}\right.$ or $57 \%$ at $\left.700^{\circ} \mathrm{C}\right)$. For clarity the power density gains in comparison to 1.35 bar are shown also in table I.

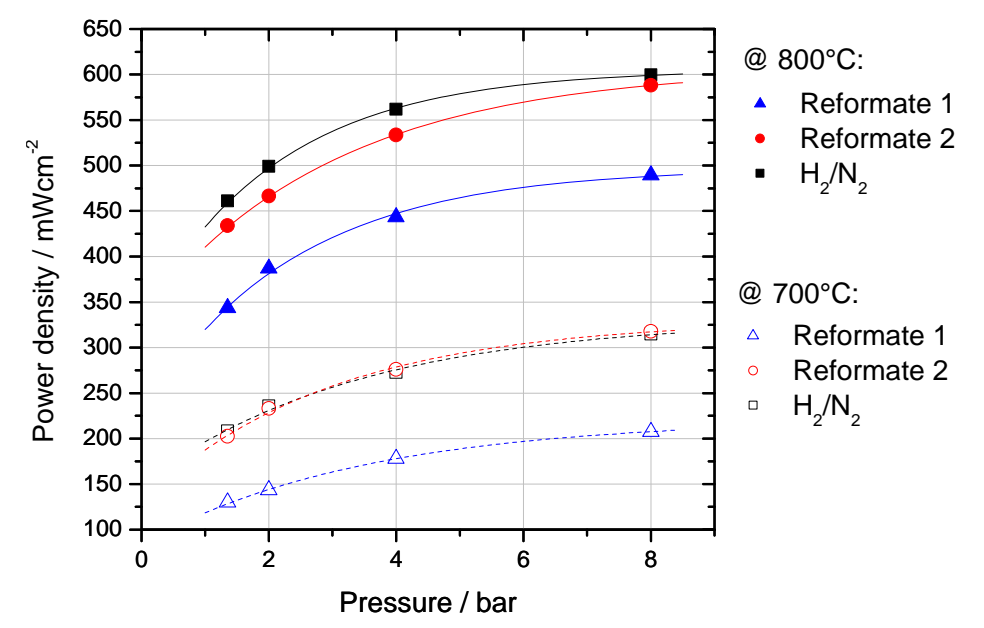

Figure 10: Power density at $750 \mathrm{mV}$ cell voltage at different pressures

\begin{tabular}{|c|c|c|c|c|c|c|}
\hline \multirow[t]{2}{*}{$700^{\circ} \mathrm{C}$} & \multicolumn{2}{|c|}{$\rightarrow 2$ bar } & \multicolumn{2}{|c|}{$\rightarrow 4$ bar } & \multicolumn{2}{|c|}{$\rightarrow 8$ bar } \\
\hline & $\mathrm{mW} / \mathrm{cm}^{2}$ & $\%$ & $\mathrm{~mW} / \mathrm{cm}^{2}$ & $\%$ & $\mathrm{~mW} / \mathrm{cm}^{2}$ & $\%$ \\
\hline $\mathrm{H}_{2} / \mathrm{N}_{2}$ & 28 & 13 & 65 & 31 & 106 & 51 \\
\hline Reformate 1 & 14 & 11 & 48 & 37 & 78 & 60 \\
\hline Reformate 2 & 30 & 15 & 73 & 36 & 115 & 57 \\
\hline
\end{tabular}

\begin{tabular}{|l|c|c|c|c|c|c|}
\hline \multicolumn{1}{|c|}{$\mathbf{8 0 0}^{\circ} \mathbf{C}$} & \multicolumn{2}{|c|}{$\mathbf{2}$ bar } & \multicolumn{2}{c|}{$\rightarrow \mathbf{4}$ bar } & \multicolumn{2}{c|}{$\rightarrow \mathbf{8}$ bar } \\
\hline & $\mathbf{m W / \mathbf { c m } ^ { \mathbf { 2 } }}$ & $\mathbf{\%}$ & $\mathbf{m W} / \mathbf{c m}^{\mathbf{2}}$ & $\mathbf{\%}$ & $\mathbf{m W / \mathbf { c m } ^ { 2 }}$ & $\mathbf{\%}$ \\
\hline $\mathrm{H}_{2} / \mathrm{N}_{2}$ & 38 & 8 & 101 & 22 & 138 & 30 \\
\hline Reformate 1 & 43 & 13 & 99 & 29 & 146 & 42 \\
\hline Reformate 2 & 33 & 8 & 100 & 23 & 154 & 35 \\
\hline
\end{tabular}

At a higher cell voltage tendencies are similar with only minor differences. In Figure 11 power densities for different pressures at a cell voltage of $850 \mathrm{mV}$ are shown. At 850 $\mathrm{mV}$ the absolute power density level is lower for all fuels compared to $750 \mathrm{mV}$. The absolute power density gain through pressurization is also lower although the relative increase in performance is greater. At this voltage the absolute power density gain for reformate 1 which contains a greater part of methane shows a smaller gradient than the 
other fuels for both temperatures $\left(51 \mathrm{~mW} / \mathrm{cm}^{2}\right.$ at $700^{\circ} \mathrm{C}$ and $108 \mathrm{~mW} / \mathrm{cm}^{2}$ at $800^{\circ} \mathrm{C}$ ) while relative power density gain is highest (70\% and 55\%). Although the hydrogen/nitrogen mixture shows the highest performance for both temperatures, reformate 2 shows the greatest increase in absolute power density gain of the examined fuels $\left(80 \mathrm{~mW} / \mathrm{cm}^{2}\right.$ at $700^{\circ} \mathrm{C}$ and $134 \mathrm{~mW} / \mathrm{cm}^{2}$ at $\left.800^{\circ} \mathrm{C}\right)$ while the hydrogen/nitrogen mixture gains $77 \mathrm{~mW} / \mathrm{cm}^{2}$ at $700^{\circ} \mathrm{C}$ and $118 \mathrm{~mW} / \mathrm{cm}^{2}$ at $800^{\circ} \mathrm{C}$. For clarity the values are shown again in table II.

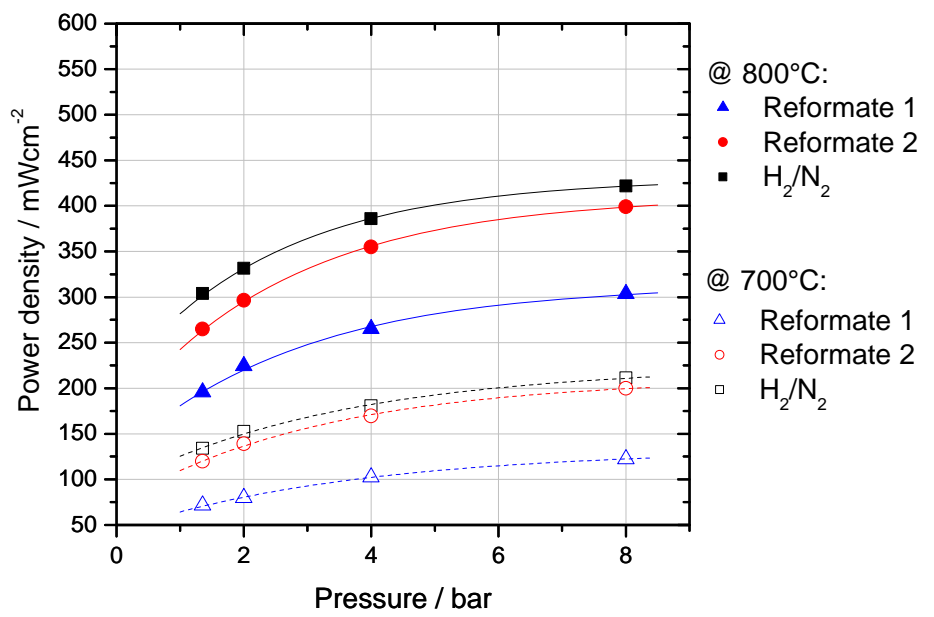

Figure 11: Power density at $850 \mathrm{mV}$ cell voltage at different pressures.

TABLE II: Power density gain through pressurization at $850 \mathrm{mV}$ compared to 1.35 bar.

\begin{tabular}{|l|c|c|c|c|c|c|}
\hline \multicolumn{1}{|c|}{$\mathbf{7 0 0}^{\circ} \mathbf{C}$} & \multicolumn{2}{|c|}{$\boldsymbol{\rightarrow} \mathbf{2 ~ b a r}$} & \multicolumn{2}{c|}{$\rightarrow \mathbf{4}$ bar } & \multicolumn{2}{c|}{$\rightarrow \mathbf{8}$ bar } \\
\hline & $\mathbf{m W / \mathbf { c m } ^ { 2 }}$ & $\mathbf{\%}$ & $\mathbf{m W / \mathbf { c m } ^ { 2 }}$ & $\mathbf{\%}$ & $\mathbf{m W / \mathbf { c m } ^ { 2 }}$ & $\mathbf{\%}$ \\
\hline $\mathrm{H}_{2} / \mathrm{N}_{2}$ & 18 & 14 & 46 & 35 & 77 & 57 \\
\hline Reformate 1 & 8 & 4 & 31 & 43 & 51 & 70 \\
\hline Reformate 2 & 19 & 16 & 50 & 41 & 80 & 67 \\
\hline
\end{tabular}

\begin{tabular}{|l|c|c|c|c|c|c|}
\hline \multicolumn{1}{|c|}{$\mathbf{8 0 0}^{\circ} \mathbf{C}$} & \multicolumn{2}{|c|}{$\boldsymbol{\rightarrow} \mathbf{2 ~ b a r}$} & \multicolumn{2}{c|}{$\rightarrow \mathbf{4}$ bar } & \multicolumn{2}{c|}{$\rightarrow \mathbf{8}$ bar } \\
\hline & $\mathbf{m W / \mathbf { c m } ^ { 2 }}$ & $\mathbf{\%}$ & $\mathbf{m W / \mathbf { c m } ^ { 2 }}$ & $\mathbf{\%}$ & $\mathbf{m W / \mathbf { c m } ^ { 2 }}$ & $\mathbf{\%}$ \\
\hline $\mathrm{H}_{2} / \mathrm{N}_{2}$ & 28 & 9 & 82 & 27 & 118 & 39 \\
\hline Reformate 1 & 29 & 15 & 69 & 35 & 108 & 55 \\
\hline Reformate 2 & 31 & 12 & 90 & 34 & 134 & 51 \\
\hline
\end{tabular}

\section{$\underline{\text { Performance gain under pressure at constant current density }}$}

If power density is regarded at constant current density instead of constant voltage the power density increase through pressurization is smaller. Figure 12 shows the development of power density under pressure at a constant current density of $0.4 \mathrm{~A} / \mathrm{cm}^{2}$. As in Figure 10 the full symbols are the measured values at $800^{\circ} \mathrm{C}$, the open symbols at 
$700^{\circ} \mathrm{C}$. At $700^{\circ} \mathrm{C}$ the curve for reformate 1 fuel is missing since for that condition 0.4 $\mathrm{A} / \mathrm{cm}^{2}$ were only reached at 8 bar.

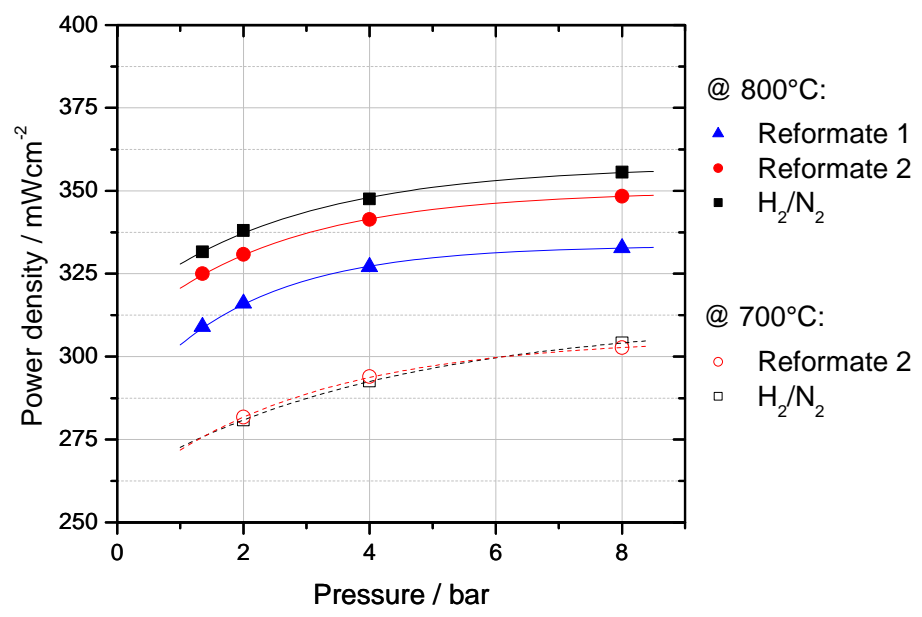

Figure 12: Power density at constant current density of $0.4 \mathrm{~A} / \mathrm{cm}^{2}$.

Power density increase through pressurization is similar for all fuels as can be seen also from table III. A pressure increase from 1.35 to 8 bar at $800^{\circ} \mathrm{C}$ leads to an increase of $24 \mathrm{~mW} / \mathrm{cm}^{2}$ for the $\mathrm{H}_{2} / \mathrm{N}_{2}$ mixture and reformate 1 . For reformate 2 the increase is 23 $\mathrm{mW} / \mathrm{cm}^{2}$. The relative increase in power density is $7 \%$ for $\mathrm{H}_{2} / \mathrm{N}_{2}$ and reformate 2 and $8 \%$ for reformate 1 . At $700^{\circ} \mathrm{C}$ there is hardly any difference in performance for the $\mathrm{H}_{2} / \mathrm{N}_{2}$ mixture and reformate 2 .

\begin{tabular}{|c|c|c|c|c|c|c|}
\hline \multicolumn{7}{|c|}{$\begin{array}{l}\text { TABLE III: Power density gain through pressurisation at } 0.4 \mathrm{~A} / \mathrm{cm} \\
\text { compared to } 1.35 \text { bar. }\end{array}$} \\
\hline \multirow[t]{2}{*}{$800^{\circ} \mathrm{C}$} & \multicolumn{2}{|c|}{$\rightarrow 2$ bar } & \multicolumn{2}{|c|}{$\rightarrow 4$ bar } & \multicolumn{2}{|c|}{$\rightarrow 8$ bar } \\
\hline & $\mathbf{m W} / \mathbf{c m}^{2}$ & $\%$ & $\mathbf{m W} / \mathbf{c m}^{2}$ & $\%$ & $\mathbf{m W} / \mathbf{c m}^{2}$ & $\%$ \\
\hline $\mathrm{H}_{2} / \mathrm{N}_{2}$ & 6 & 2 & 16 & 5 & 24 & 7 \\
\hline Reformate 1 & 7 & 2 & 18 & 6 & 24 & 8 \\
\hline Reformate 2 & 6 & 2 & 16 & 5 & 23 & 7 \\
\hline
\end{tabular}

At $700^{\circ} \mathrm{C}$ the increase in power density is slightly higher than at $800^{\circ} \mathrm{C}$. For the hydrogen/nitrogen mixture and reformate 2 power density increases by $23 \mathrm{~mW} / \mathrm{cm}^{2}$ and $21 \mathrm{~mW} / \mathrm{cm}^{2}$ respectively when increasing pressure from 2 bar to 8 bar at $700^{\circ} \mathrm{C}$ while at $800^{\circ} \mathrm{C}$ the increase is $18 \mathrm{~mW} / \mathrm{cm}^{2}$.

\section{Summary}

The behavior of pressurized solid oxide fuel cells was examined using reformates as fuel. Two different reformate gases were used as well as a hydrogen/nitrogen mixture with $3 \%$ of water. Reformate 1 contained $18 \% \mathrm{H}_{2}, 34 \% \mathrm{H}_{2} \mathrm{O}, 2 \% \mathrm{CO}, 27 \% \mathrm{CO}_{2}$ and 
$19 \% \mathrm{CH}_{4}$ while reformate 2 contained $58.4 \% \mathrm{H}_{2}, 20 \% \mathrm{H}_{2} \mathrm{O}, 12.2 \% \mathrm{CO}, 5.5 \% \mathrm{CO}_{2}$ and $3.9 \% \mathrm{CH}_{4}$. Measurements were done at $700^{\circ} \mathrm{C}$ and $800^{\circ} \mathrm{C}$ at pressures ranging from 1.35 bar to 8 bar.

Pressure dependency of OCV was found to be highest for the hydrogen/nitrogen mixture. The pressure increase of OCV through pressurization for reformates showed a strong dependency on temperature. At lower temperatures the increase in OCV with pressure was found to be considerably smaller than for higher temperatures. This was explained by considering the gas compositions in equilibrium for the different temperatures as well as measurements of the gas composition after the stack. Measurements and calculated equilibrium compositions showed a good agreement. At lower temperatures gas composition varied strongly with pressure resulting in smaller hydrogen content at high pressures, which explains the smaller gain in OCV.

Under load pressurization showed a positive effect on performance for all fuels. At constant voltage a higher temperature led to a higher increase in power density for all fuels. The absolute increase in power density was found to be greatest for reformate 2 where up to $154 \mathrm{~mW} / \mathrm{cm}^{2}$ were gained at a voltage of $750 \mathrm{mV}$ while the relative increase was greatest for reformate 1 which contained the greater part of methane and for which up to $70 \%$ of power increase was measured. The lower the voltage the greater was the absolute increase in power density through pressure while the relative increase got smaller. At constant current density the increase in power density because of pressure was similar for all fuels. At a current density of $0.4 \mathrm{~A} / \mathrm{cm}^{2}$ an increase of $24 \mathrm{~mW} / \mathrm{cm}^{2}$ or $8 \%$ was obtained.

\section{References}

1. S. Singhal, K. Kendall, High Temperature Solide Oxide Fuel Cells Fundamentals, Design and Application, Elsevier, Oxford, pp. 374 (2003).

2. T. Panne, A.Widenhorn, J. Boyde, D. Matha, V. Abel, M. Aigner, Thermodynamic Process Analyses of SOFC/GT Hybrid Cycles, 5th International Energy Conversion Engineering Conference and Exhibit, St. Luis, Missouri (2007).

3. S. Seidler, M. Henke, J. Kallo, W.G. Bessler, U. Maier and K.A. Friedrich, Pressurized solid oxide fuel cells: Experimental studies and modeling. Journal of Power Sources, 196, p. 7195-7202 (2011).

4. M. Lang, C. Westner, R.Geieregger, B. Bentlohner, R.Schwub, SOFC Stacks for Mobile Applications, European Solid Oxide Fuel Cell Forum, Lucerne, Switzerland (2010).

5. D.G. Goodwin, An Open-Source, Extensible Software Suite for CVD Process Simulation. in Proceedings of Chemical Vapor Deposition XVI and EUROCVD 14, Electrochemical Society (2003). 